\title{
1 Recombinant production of human ICAM-1 chimeras by single step on column
}

2 refolding and purification.

3 David Núñez ${ }^{1,2}$, María Pilar Domingo ${ }^{1,2}$, Diego Sánchez-Martínez ${ }^{2,3}$, Vicente Cebolla ${ }^{1}$, 4 Arthur Chiou, Adrián Velázquez-Campoy ${ }^{3,5,6}$, Julián Pardo ${ }^{2,3,6,7 \ddagger}$ and Eva $\mathrm{M}^{\mathrm{a}}$ 5 Gálvez ${ }^{1,2} * \$$

$6 \quad{ }^{1}$ Instituto de Carboquímica ICB-CSIC, Zaragoza, Spain

$7 \quad{ }^{2}$ Immune Effector Cells Group, Aragón Health Research Institute (IIS Aragón),

8 Biomedical Research Centre of Aragón (CIBA)

$9{ }^{3}$ Dpt. Biochemistry and Molecular and Cell Biology, Fac. Ciencias, University of

10 Zaragoza, Zaragoza, Spain

$11{ }^{4}$ Institute of Biophotonics, National Yang-Ming University, Taipei, Taiwan

$12{ }^{5}$ Institute of Biocomputation and Physics of Complex Systems (BIFI), Unidad

13 Asociada IQFR-CSIC-BIFI, Universidad de Zaragoza, Zaragoza, Spain.

$14{ }^{6}$ Aragón I+D Foundation (ARAID), Government of Aragon, Zaragoza, Spain

$15{ }^{7}$ Nanoscience Institute of Aragon (INA). Aragón I+D Foundation (ARAID). University

16 of Zaragoza, Zaragoza, Spain

17

18 * Corresponding author. Tel.: +34-976733977. E-mail address: eva@icb.csic.es (E.

19 Galvez).

$20 \$$ These authors contributed equally to this work.

23 Keywords: Adhesion molecules, on-column refolding, LFA-1 


\section{Summary}

25 The interaction of the adhesion molecule of the immunoglobulin family Intercellular 26 Adhesion Molecule 1 (ICAM-1) with its ligands such the integrins LFA-1 and Mac-1 is 27 crucial for the regulation of several physiological and pathophysiological processes like 28 cell mediated-elimination of tumor or virus infected cells, cancer metastasis or inflammatory autoimmune processes. Thus, production of milligrams of protein is required to perform structural and functional studies as well as design novel approaches

31 to find out new inhibitors of ICAM-1/LFA-1 interaction. Here we report on the 32 production of a recombinant human ICAM-1 chimera comprising the first two 33 extracellular domains of ICAM-1 linked to the Fc fraction of a human IgG1. To this aim 34 we have used a cost-effective method based on the expression of a His-tagged protein in 35 E. coli followed by a single step of refolding and purification on immobilized metal 36 affinity columns. This method is able to produce $3 \mathrm{mg} /$ liter of bacterial culture in just 72 37 hours with purity greater than $95 \%$. The identity and the native structure of refolded 38 human ICAM-1 chimera were confirmed by biochemical and biophysical studies including SDS-electrophoresis, immunoblot, circular dichroism, isothermal titration

40 calorimetry and fluorescence spectroscopy. Native folding and functional activity of the 41 chimera were further confirmed by different cell biology studies, including B cell 42 adhesion, $\mathrm{T}$ cell binding and inhibition of NK cell function. These studies indicate a 43 high biological activity of the protein since it induces a 200 -fold increase $/ \mathrm{mg}$ of protein 44 in B cell adhesion and the Inhibitory Dose 50 to block cell-mediated cytotoxicity is 10 $\mathrm{pg} / \mathrm{effector}$ cell. These analyses show that our protocol is able to produce a recombinant human ICAM-1 chimera fully active and useful to analyse the biological processes in which ICAM-1/LFA-1 interaction is critically involved. 


\section{Introduction}

The intercellular adhesion molecule 1 (ICAM-1) is a membrane glycoprotein, member of the immunoglobulin superfamily (IgSF) and responsible for mediating cell-cell and cell-extracellular matrix interactions [1-3]. In addition, ICAM-1 is the receptor for different human viruses like rhinovirus [4] and coxsackievirus A21 as well as for the malarial parasite Plasmodium falciparum [5-7]. ICAM-1 is formed by 5 extracellular immunoglobulin domains, a hydrophobic transmembrane domain and a short cytoplasmic tail and expressed by several cell types including endothelial and epithelial cells and most types of leukocytes including $\mathrm{B}$ and $\mathrm{T}$ lymphocytes, NK cells and monocytes [3] [1]. Although the protein is heavily glycosylated, glycosylation does not affect the interaction between ICAM-1 and the integrin LFA-1 $[8,9]$. This interaction occurs between domain 1 of ICAM-1 [10] and a metal ion-dependent adhesion site (MIDAS) motif located in the integrin $\alpha$ subunit I domain $[11,12]$. Domain 1 of ICAM1 also contains the interaction site with human rhinovirus [13] and Plasmodium falciparum [5] as well as for the extracellular matrix protein fibrinogen [14]. The integrin Mac1 binds to domain 3 of ICAM-1 [8]. ICAM-1 is expressed as a dimer in the plasma membrane of cells and this form binds more efficiently to LFA-1 than monomeric ICAM-1 [15, 16]. However, the crystal structure of dimeric ICAM-1 suggests that the dimer is not required for binding of LFA-1 and rhinovirus [17], which occurs by a single molecule of ICAM-1 [18]. In fact monomeric recombinant ICAM-1 prevents development of insulitis during autoimmune diabetes [19]. Finally, it has been recently reported that the equilibrium between monomeric and dimeric state regulates the binding to LFA-1 [20].

The interaction of ICAM-1 with LFA-1 regulates several physiological and pathophysiological processes related with lymphocyte extravasation to inflammatory sites and selective entry into lymphoid organs (lymphocyte homing) [3, 21, 22]. In addition, this interaction is critically involved in cell-cell adhesion during antigen presentation and during the recognition and elimination of tumor or virus-infected cells [23]. Apart from its beneficial effect in the elimination of tumor cells and pathogens, ICAM-1/LFA-1 interaction is also involved in diverse pathologies involving inflammation and/or cellular extravasation [24]. It has been shown that specific tumour cells use this interaction to disseminate and spread to other tissues or organs [25-27] and that ICAM-1 expression contributes to drug resistance in multiple myeloma [28]. In 
86 addition, lymphocyte extravasation and accumulation in diverse tissues mediated by

87 LFA-1 is associated with inflammatory diseases like Rheumathoid Arthritis [29], 88 Atherosclerosis [30] and Inflammatory Bowel Disease [31, 32] among others.

89 Altogether, these findings suggest that targeting ICAM-1/LFA-1 interaction may help to 90 inhibit tumor spreading [33] or to treat inflammatory disorders [33, 34] [35].

91 Several chromatographic approaches have been previously developed in order to purify 92 and refold recombinant mammal proteins produced in bacterial systems. Among them 93 Immobilised Metal Affinity Chromatography (IMAC) has been proved to be especially 94 useful to purify proteins genetically modified to contain an amino- or carboxy-terminal 95 polyhistidine sequences (His-Tag). This type of affinity chromatography is based on the 96 ability of divalent cations like $\mathrm{Cu}^{2+}, \mathrm{Co}^{2+}$ or $\mathrm{Ni}^{2+}$ to bind imidazole groups from 97 histidine residues [36, 37]. In order to bind efficiently the protein multiple histidine 98 groups must located in close proximity. Very few proteins fulfil this prerequisite and, 99 thus, this type of chromatography simplifies the whole purification process. This is 100 especially true if purification is performed under denatured conditions, since the 101 possibility of histidine groups closely located due to the native three-dimensional 102 structure is eliminated.

103 One of the main problems of producing mammal proteins in prokaryotic systems is that 104 proteins are usually expressed as a type of insoluble material known as inclusion bodies. 105 In order to circumvent this problem and get functional proteins in native form in vitro 106 refolding must be performed.

107 Among the different protocols used to refold proteins in vitro, [38], it seems that 108 addition of detergents to refolding buffer helps to minimise the formation of aggregates 109 and improves the refold efficiency [39]. A singular advance to avoid the use of large 110 amounts of buffers and time invested in refolding by dilution was the introduction of the 111 on column refolding [40]. Most types of chromatographic methods have been used to 112 refold proteins on columns including size exclusion chromatography [41, 42] 113 immobilization on gel matrices [43], hydrophobic interaction chromatography [44], 114 affinity chromatography [45], immobilized liposome chromatography [46] and IMAC $115 \quad[40,47-50]$.

116 Generation of purified active forms of ICAM-1 is very important to study the above117 mentioned functions. Specially, the availability of large amounts of active ICAM-1 is 
118 crucial to design efficient and specific approaches to find new inhibitors of ICAM-

119 1/LFA-1 interaction.

120 To this aim we have established a simple and fast protocol to generate large quantities

121 of active ICAM-1 chimera in Escherichia coli by reducing the timing and reagents and, 122 thus, improving the efficiency of the process. His-tagged protein is expressed in bacteria 123 as inclusion bodies and refolded and purified in a single step by using Immobilised 124 Metal Affinity Chromatography (IMAC). Our method shows a reduction in total 125 process time of up to $500 \%$ and decreases the cost of up to $150 \%$ in comparison with 126 refolding by dilution, the most common protocol to purify ICAM-1 in E. coli [9]. The 127 purity of ICAM-1 is greater than $95 \%$ and the yield is $3 \mathrm{mg} /$ liter of bacterial culture. 128 Moreover, the activity of ICAM-1 has been proven by using biochemical, biophysical 129 and cell biology models.

130 
Plasmids and bacterial strains

133 Two synthetic cDNAs corresponding to the first two domains $\left(\mathrm{D}_{1} \mathrm{D}_{2}\right)$ of human ICAM1

134 or $\mathrm{D}_{1} \mathrm{D}_{2}$ linked to human $\mathrm{IgG1} \mathrm{Fc}$ region cloned into $\mathrm{pET} 28 \mathrm{a}(+)$ plasmid at $\mathrm{NdeI} / \mathrm{EcoR} 1$

135 sites (Figure 1) were purchased from GenScript (Piscataway, NJ, USA). Plasmids were

136 transformed into chemically competent BL21 Escherichia coli strain BL21 CodonPlus

137 (Novagen) for high-level protein expression. The proteins expressed by using these

138 constructs contain a 6 histidine-tag at the N-terminal site.

\section{Expression and Purification of $D_{1} D_{2} F c$ and $D_{1} D_{2}$}

141 Bacterial cultures containing pET28a- $\mathrm{D}_{1} \mathrm{D}_{2} \mathrm{Fc}$ or $\mathrm{pET} 28 \mathrm{a}-\mathrm{D}_{1} \mathrm{D}_{2}$ were grown at $37^{\circ} \mathrm{C}$ 142 until the optical density (OD) at $600 \mathrm{~nm}$ reached 0.6-0.8. Subsequently, protein 143 expression was induced by adding isopropyl-beta-D-1-galactopyranoside (IPTG) to a

144 final concentration of $1 \mathrm{mM}$ for $3 \mathrm{~h}$ at $37^{\circ} \mathrm{C}$. After protein induction cells were recovered 145 by centrifugation at $17,700 \mathrm{~g}$ for $8 \mathrm{~min}$ at $4^{\circ} \mathrm{C}$. Proteins were solubilised from inclusion 146 bodies by resuspending the cell pellets in $6 \mathrm{M}$ guanidine hydrochloride $(\mathrm{GdmCl})$ at 147 room temperature with gently shaking overnight. Subsequently, cell suspension was 148 centrifuged at $48,400 \mathrm{~g}$ for $30 \mathrm{~min}$ at $4^{\circ} \mathrm{C}$ to pellet cellular debris. Supernatants 149 containing the soluble proteins were then recovered and incubated for 1 hour at room 150 temperature with Ni-NTA resin (Qiagen, Hilden, Germany) to allow the polyhistidine 151 tag to bind to the resin. After centrifugation at $157 \mathrm{~g}$ for $2 \mathrm{~min}$, most of the supernatant 152 was carefully removed and then resin was resuspended in the remaining supernatant, transferred to a gravity-flow column and allowed to settle.

154 On-column renaturation and purification was performed by several changes of buffers 155 following a modified protocol based on that described by Oganesyan [47]. First, the 156 column was washed using the denaturing buffer containing $20 \mathrm{mM}$ imidazole to remove 157 non-specifically-bound contaminants and mercaptoethanol $10 \mathrm{mM}$ to reduce disulfide 158 bonds. Then, renaturation was carried on using buffer A (20mM Tris- $\mathrm{HCl} \mathrm{pH} 8.0,0.1 \mathrm{M}$ $159 \mathrm{NaCl})$. In the first step, the column was washed with 10-column volumes (CV) of buffer 160 A containing $0.1 \%$ Triton X-100 and mercaptoethanol 10mM. Next, resin was washed 161 with $10 \mathrm{CV}$ of buffer A containing $5 \mathrm{mM}$ Methyl- $\beta$-cyclodextrin (Sigma, St.Louis, 162 Missouri, USA) to remove detergent from the protein-detergent complex and to allow 163 the protein to refold. The last wash before elution was performed with $20 \mathrm{mM}$ Tris- $\mathrm{HCl}$ $164 \mathrm{pH} 8.0,0.5 \mathrm{M} \mathrm{NaCl}$ to remove remaining impurities and Methyl- $\beta$-cyclodextrin. All 
165 steps were performed in the presence of a cocktail of protease inhibitors (Roche, Basel,

166 Switzerland). Refolded protein was eluted with buffer A containing $1 \mathrm{M}$ imidazole and 167 protein concentration was measured using a spectrophotometer (NanoView, Healthcare,

168 Waukesha, WI, USA). Fractions containing the highest levels of protein were passed 169 through a desalting column (PD-10 Desalting Columns, GE Healthcare, Waukesha, WI,

170 USA) following manufacturer's instructions and the protein was recovered in phosphate 171 buffered saline (PBS). Protein concentration was adjusted to $500 \mu \mathrm{g} / \mathrm{ml}$ by ultrafiltration 172 using 10,000 MWCO Centrifugal Filter Units (Amicon, Millipore, Billerica, MA, USA) 173 and stored at $-20^{\circ} \mathrm{C}$. The level of protein expression after IPTG induction and the quality 174 of purified proteins was evaluated by sodium dodecyl sulfate polyacrylamide gel 175 electrophoresis (SDS-PAGE) under reducing conditions and staining with Coomassie 176 Blue.

177

178 Western blot analysis

179 Purified $D_{1} D_{2} F c$ and $D_{1} D_{2}$ was analysed by western blotting under reducing conditions 180 by using a mouse mAb against human CD54/ICAM1 (clone 28/CD54; BD bioscience, 181 San Jose, CA, USA; dilution 1:1000) or a mouse mAb against HisTag (Novagen, 182 Madison, WI, USA; dilution 1:1000). Then, the blot was stained with peroxidase183 conjugated secondary antibodies, rabbit anti-mouse (Amersham, Piscataway, NJ, USA; 184 dilution 1:10000). Subsequently, a peroxidase substrate for enhanced 185 chemiluminescence (ECL) from Pierce (Rockford, IL, USA) was used for detection.

\section{Circular dichroism spectroscopy}

188 Secondary structure of proteins was examined using circular dichroism (CD) in a

189 Chirascan spectropolarimeter (Applied Photophysics). Spectra were recorded in the far 190 ultraviolet region $(200 \mathrm{~nm}-250 \mathrm{~nm})$ with a protein concentration of $6 \mu \mathrm{M}$ in PBS

191 (Phosphate buffered saline) and a scan rate of $1 \mathrm{~nm} / \mathrm{s}$. The temperature was controlled 192 by a Peltier controller. It was employed a quartz cuvette $0.1 \mathrm{~cm}$ path length.

\section{Fluorescence Spectroscopy}

195 Protein samples were characterized by fluorescence spectroscopy using a Cary Eclipse

196 spectrofluorometer (Varian, Palo Alto, CA, USA) thermostated by a Peltier temperature 197 control unit, employing either the fluorescence emission from the internal tryptophan 198 residues or from the ANS (8-anilino-1-naphthalenesulfonic acid) extrinsic probe. When 
convenient, the fluorescence intensity at a certain wavelength, $\mathrm{I}_{\lambda}$, or the average energy of the spectrum:

201

202

Average Energy $! \frac{!_{\mathrm{n}} \mathrm{I}_{!} \mathrm{e}^{! 1}}{!_{\mathrm{n}}^{\mathrm{I}}}$

203

204

was considered as the reporting signal. Protein samples were excited at $290 \mathrm{~nm}$ and 390

205

$\mathrm{nm}$ when tryptophan and ANS spectra were recorded, respectively, with a slit width of 5 $\mathrm{nm}$.

Thermal unfolding assays were conducted in order to assess the structural stability of the proteins. An unfolding model considering an intermediate partially folded state was employed:

210

211

$S(T)=F_{N}(T) I_{N}(T)+F_{I}(T) I_{I}(T)+F_{U}(T) I_{U}(T)$

212

213

where $\mathrm{T}$ is the absolute temperature; $\mathrm{S}(\mathrm{T})$ is either the fluorescence intensity at a certain wavelength or the average energy of the spectrum; $I_{N}, I_{I}$ and $I_{U}$ are the intrinsic contributions to the fluorescence of each conformational state, that are assumed to exhibit a linear dependency with the temperature:

217

218

219

220

$I_{X}(T)=a_{X}+b_{X} T$

and $F_{N}(T), F_{I}(T)$ and $F_{U}(T)$ are the fraction population of each conformational state (native, intermediate and unfolded) and can be expressed in terms of the equilibrium constants associated with each conformational transition, $\mathrm{K}_{1}(\mathrm{~T})$ and $\mathrm{K}_{2}(\mathrm{~T})$ :

223

225

226

227

228

229
$\mathrm{F}_{\mathrm{N}}(\mathrm{T}) ! \frac{1}{1 ! \mathrm{K}_{1}(\mathrm{~T}) ! \mathrm{K}_{1}(\mathrm{~T}) \mathrm{K}_{2}(\mathrm{~T})}$

$\mathrm{F}_{\mathrm{N}}(\mathrm{T}) ! \frac{\mathrm{K}_{1}(\mathrm{~T})}{1 ! \mathrm{K}_{1}(\mathrm{~T}) ! \mathrm{K}_{1}(\mathrm{~T}) \mathrm{K}_{2}(\mathrm{~T})}$

$$
\mathrm{F}_{\mathrm{N}}(\mathrm{T}) ! \frac{\mathrm{K}_{1}(\mathrm{~T}) \mathrm{K}_{2}(\mathrm{~T})}{1 ! \mathrm{K}_{1}(\mathrm{~T}) ! \mathrm{K}_{1}(\mathrm{~T}) \mathrm{K}_{2}(\mathrm{~T})}
$$

The equilibrium constants are also temperature dependent:

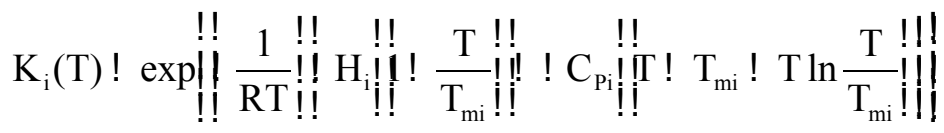


230 where $\mathrm{R}$ is the ideal gas constant, $\mathrm{T}_{\mathrm{mi}}$ is the unfolding (or mid-transition) temperature,

$231 \Delta \mathrm{H}_{\mathrm{i}}$ is the unfolding enthalpy, and $\Delta \mathrm{C}_{\mathrm{Pi}}$ is the unfolding heat capacity for each transition

232 i. Non-linear square regression data analysis implemented in Origin (OriginLab)

233 provides the unfolding parameters $\left(\mathrm{T}_{\mathrm{mi}}, \Delta \mathrm{H}_{\mathrm{i}}\right.$, and $\left.\Delta \mathrm{C}_{\mathrm{Pi}}\right)$ for both proteins, $\mathrm{D}_{1} \mathrm{D}_{2} \mathrm{Fc}$ and

$234 \mathrm{D}_{1} \mathrm{D}_{2}$.

235

236

Isothermal titration calorimetry

237 The ability of $\mathrm{D}_{1} \mathrm{D}_{2} \mathrm{Fc}$ to interact with a peptide derived from its natural ligand LFA-1

238 was analysed by isothermal titration calorimetry (ITC) on a VP-ITC calorimeter

239 (MicroCal) at $25{ }^{\circ} \mathrm{C}$. The peptide sequence was DSGNIDAAKD corresponding to

240 aminoacids 244-253 from LFA-1 [51]. $2.2 \mathrm{ml}$ of a $12 \mu \mathrm{M}$ solution of $\mathrm{D}_{1} \mathrm{D}_{2} \mathrm{Fc}$ and $0.6 \mathrm{ml}$

241 of a $150 \mathrm{mM}$ solution of peptide were prepared in PBS and degassed with a vacuum

242 pump for $10 \mathrm{~min}$. Protein solution was carefully injected into the cell previously washed

243 with PBS. Each assay consisted of a series of 28 injections of peptide solution of $10 \mathrm{ul}$

244 each (with a 4- $\mu$ l first onjection) at $400 \mathrm{~s}$ intervals under constant stirring (459 rpm).

245 The thermal power required to keep the cell at a constant temperature is measured, so

246 that it provides the heat associated with each ligand injection after integrating the signal

247 over time. The thermodynamic parameters of protein-peptide interactions (affinity,

248 enthalpy and entropy changes) as well as the stoichiometry were estimated by using

249 nonlinear regression analysis. Data were analyzed using the software developed and

250 implemented in Origin 7.0 (OriginLab).

251

252 Cell Adhesion assay

253 The ability of ICAM1 chimera $\left(\mathrm{D}_{1} \mathrm{D}_{2} \mathrm{Fc}\right)$ to induce cell adhesion of non-adherent cells

254 expressing LFA-1 was analysed by using the EBV transformed human B

255 lymphoblastoid cell line R69, a generous gift from José A. López de Castro [52].

256 Adhesion assay was performed in flat bottom 96-well plates in which different amounts

257 of ICAM-1 chimera or human IgG1 (Fc control) had been previously immobilized for

$25818 \mathrm{~h}$ at $4^{\circ} \mathrm{C}$. R69 human cells were washed twice in DMEM medium supplemented with

$25910 \%$ fetal bovine serum, $2 \mathrm{mM} \mathrm{L-glutamine}$ and antibiotics (penicillin $100 \mathrm{U} / \mathrm{ml}$, 260 streptomycin $100 \mu \mathrm{g} / \mathrm{ml}$ ) and resuspended at a final concentration of $10^{6} \mathrm{cells} / \mathrm{ml}$. Then,

261 LFA-1 expression was induced by incubating cells with $10 \mathrm{ng} / \mathrm{ml}$ PMA for 2 hours at

$26237^{\circ} \mathrm{C}$ [53]. Subsequently, $1 \times 10^{5}$ cells were added to each well and incubated at $37^{\circ} \mathrm{C}$ for 
2634 hours. To quantify the number of adherent cells a modification of the MTT

264 colorimetric test designed by Mosmann [54] was used.

265

266 Flow cytometry (FACS)

267 The ability of $\mathrm{D}_{1} \mathrm{D}_{2} \mathrm{Fc}$ to quantify the expression of LFA-1 on cells was analysed by

268 flow cytometry in the human T leukemia cell line Jurkat (clon E6-1, ATCC). Jurkat 269 cells were incubated with different concentrations of $\mathrm{D}_{1} \mathrm{D}_{2} \mathrm{Fc}$ or human $\mathrm{IgG1}$ control at $27044^{\circ} \mathrm{C}$ for $30 \mathrm{~min}$, washed twice with FACS buffer (PBS, 5\% FCS, 0,1\% $\mathrm{NaN}_{3}$ ) and then 271 incubated with PE-conjugated goat anti-human IgG (Fc $\gamma$ fragment specific; Jackson 272 ImmunoResearch). After a washing step with FACS buffer, cells were analysed by 273 FACS using a FACSCalibur with CellQuest Pro software (BD).

274

275 Cytotoxicity assay

276 The effect of $\mathrm{D}_{1} \mathrm{D}_{2} \mathrm{Fc}$ and $\mathrm{D}_{1} \mathrm{D}_{2}$ on ICAM-1/LFA-1 dependent cell-cell contact was 277 analysed by performing a cell cytotoxicity assay using human primary NK cells and the 278 NK-cell sensitive human leukemia K562. Primary human NK cells were generated by 279 culturing human peripheral blood mononuclear cells (PBMCs) with mitomycin C 280 inactivated R69 cells for 5 days as previously described [55]. Then, NK cell fraction 281 was enriched by MACS using anti-CD56 antibodies as previously described [56]. Cell 282 cytotoxicity induced by NK cells on K562 was analyzed by flow cytometry as 283 previously described [56]. Briefly, NK cells were preincubated with medium alone or in 284 the presence of different amounts of $\mathrm{D}_{1} \mathrm{D}_{2} \mathrm{Fc}, \mathrm{D}_{1} \mathrm{D}_{2}$ or human IgG1 control for $15 \mathrm{~min}$ 285 at $37^{\circ} \mathrm{C}$. Then, they were added to $\mathrm{K} 562$ cells at different e:t cell ratio for $4 \mathrm{~h}$ at $37^{\circ} \mathrm{C}$, $2865 \% \mathrm{CO} 2$. Subsequently, phosphatidylserine exposure and AAD uptake were analyzed 287 by FACS using the annexin-V/AAD kit from BD Pharmingen. 


\section{Results and discussion}

289

290

\section{Expression of recombinant proteins}

291 First we have analysed that E. coli BL21-Codon plus cells transformed with pET28a$\mathrm{D}_{1} \mathrm{D}_{2} \mathrm{Fc}$ or $\mathrm{pET} 28 \mathrm{a}-\mathrm{D}_{1} \mathrm{D}_{2}$ overexpressed the respective proteins after induction with 293 IPTG. As shown in Figure 2A, the expression of two proteins was clearly increased 294 after 2 and 3 hours of induction. The approximate MW of these proteins was $50 \mathrm{kDa}$ 295 (lanes 2 and 3) and $25 \mathrm{kDa}$ (lanes 5 and 6), which matched well with the theoretical MWs of $\mathrm{D}_{1} \mathrm{D}_{2} \mathrm{Fc}$ and $\mathrm{D}_{1} \mathrm{D}_{2}$, respectively. In contrast, non-induced cells did not express the proteins (lanes 1 and 4). The highest level of expression was found at 3 hours and longer induction times ( 4 and $24 \mathrm{~h}$ ) did not increase that level. Thus, we chose this timepoint in the subsequent experiments.

300

\section{Purification of recombinant proteins}

302 Ni-NTA affinity chromatography was applied for the purification of $D_{1} D_{2}$ and $D_{1} D_{2} F c$ 303 poly-histidine tagged proteins. Poly-histidine tags form high affinity complexes with 304 immobilized divalent metal ions ( 305 concentrations of chaotropic agents (e.g., urea or $\mathrm{GdmCl}$ ), thereby allowing isolation of 306 tagged protein from a crude cellular extract [36, 37, 57]. In addition, these properties

307 allow to refold denatured proteins by changing the buffer composition flowing through 308 the column [40, 47-50]. Most of $\mathrm{D}_{1} \mathrm{D}_{2} \mathrm{Fc}$ and $\mathrm{D}_{1} \mathrm{D}_{2}$ exist in the bacterial cells in the form 309 of inclusion bodies that were solubilized by resuspending bacterial pellets in $6 \mathrm{M}$ $310 \mathrm{GdmCl}$. Soluble proteins were incubated with the Ni-NTA resin slurry to allow binding 311 of the poly-histidine-tagged proteins and folded as indicated in methodological section.

312 As shown in Figure 2B, non-bound proteins were washed out during the first two steps

313 of purification (lanes 3 and 4). These fractions also contained some $\mathrm{D}_{1} \mathrm{D}_{2} \mathrm{Fc}$ protein, 314 although at very low levels. Unbound proteins were not detected anymore in fractions 315 corresponding to the folding steps (lanes 5 and 6). After folding the bound proteins, 316 they were eluted by using imidazole. Most of $\mathrm{D}_{1} \mathrm{D}_{2} \mathrm{Fc}$ protein eluted in the early 317 fractions (Figure 2B, lanes 8-12) which contained a small amount of proteins of lower 318 MW, suggesting that either contaminating proteins co-eluated with $\mathrm{D}_{1} \mathrm{D}_{2} \mathrm{Fc}$ or some 319 protein degradation ocurred during the purification process. In order to confirm the 320 identity of the purified protein and of the low MW forms, we performed immunoblot 321 using mAbs specific for ICAM-1 (Figure 2C, lane 1) or for the poly-histidine tag 
322 (Figure $2 \mathrm{C}$, lane 2). As shown in the blots a single band corresponding to $\mathrm{D}_{1} \mathrm{D}_{2} \mathrm{Fc}$ was

323 detected by using anti-ICAM-1 mAb confirming the identity of the purified protein. In

324 contrast, several bands were detected with the anti-HisTag antibody. The pattern of

325 bands detected by this mAb matched those observed by Coomassie Blue staining

326 (Figure 2B), confirming that the low MW proteins contains a poly-histidine tag and,

327 thus, correspond to short forms of our fusion protein. Since poly-histidine tag is placed

328 at the N-terminal site, this result indicates that degradation of the protein occurs at the

329 C-terminal site where the Fc fraction is located. Moreover, it suggests that the epitope

330 recognised by the anti-ICAM-1 mAb is missed in the degraded proteins. Anyway, the

331 level of degradation is minimal since the intensity of the $50 \mathrm{KDa}$ band corresponding to

$332 \quad \mathrm{D}_{1} \mathrm{D}_{2} \mathrm{Fc}$ was much stronger than that of the lower bands.

333 Similar results were found when $\mathrm{D}_{1} \mathrm{D}_{2}$ protein was purified (Figure $2 \mathrm{D}$ and $2 \mathrm{E}$ ).

334 However, no degradation products were observed in the purified fraction, confirming 335 that the residual degradation of the $\mathrm{D}_{1} \mathrm{D}_{2} \mathrm{Fc}$ chimera occurred by the Fc fraction. This 336 result is not surprising since it is known that $\mathrm{Fc}$ regions are especially susceptible to the 337 action of specific proteases like pepsin-like proteases. However, this effect has been 338 minimised by including general protease inhibitors during the purification process.

339 Altogether, the results indicate that the purified protein corresponds to the recombinant

340 ICAM-1 $\mathrm{D}_{1} \mathrm{D}_{2} \mathrm{Fc}$ chimera and degradation is hardly observed. The yield obtained by

341 using this protocol is around $3 \mathrm{mg}$ per liter of bacterial culture and the entire process

342 took just 72 hours from bacterial cultures to purified protein. Of note, the purification of

343 other recombinant proteins using redolding by dilution takes about 14 days in our

344 laboratory.

\section{Circular dichroism}

347 Next we have analysed by circular dichroism (CD) whether purified ICAM-1 $\mathrm{D}_{1} \mathrm{D}_{2} \mathrm{Fc}$ 348 chimera is properly folded and presents the expected secondary structure. ICAM-1 349 belongs to the IgSF and each of its domains presents a typical Ig-like structure 350 characterised by the presence of $\beta$-sheets [58]. Dichroism spectra in the far ultraviolet 351 region are primarily due to the amide bonds linking the amino acid residues. The 352 asymmetry of these chromophores is due to the spatial arrangement of the main chain of 353 the protein, thus, the circular dichroism signals can be interpreted in terms of the 354 content of secondary structure present, i.e. the percentage of residues found in some 355 structural conformation ( $\alpha$ helix, $\beta$ sheets, turns and other structural types). 
356 As shown in Figure $3 \mathrm{~A}$ the $\mathrm{CD}$ spectrum of $\mathrm{D}_{1} \mathrm{D}_{2} \mathrm{Fc}$ shows a single broad negative

357 ellipticity centered at approximately $205 \mathrm{~nm}$. This result indicates that the protein

358 predominatly contains $\beta$ sheets or turns as secondary structures and, thus, that the

359 folding protocol renders a protein with the expected secondary structure.

360

361

Fluorescence spectroscopy

362 Both $D_{1} D_{2} F c$ and $D_{1} D_{2}$ show a fluorescence spectrum with two maxima around $330 \mathrm{~nm}$

363 and $375 \mathrm{~nm}$, in agreement with these two proteins containing several tryptophan

364 residues (Figure 3B, i).

365 In order to test the structural integrity of the proteins, fluorescence thermal

366 denaturations were performed (Figures 3B, ii-vi). Unfolding parameters for $\mathrm{D}_{1} \mathrm{D}_{2} \mathrm{Fc}$

367 following the thermal denaturation either by intrinsic tryptophan fluorescence or

368 extrinsic ANS fluorescence provided similar results (Figures 3B, ii and iv, Table 1).

369 However, for $\mathrm{D}_{1} \mathrm{D}_{2}$ only ANS fluorescence data showed a clear unfolding curve (Figure

$3703 \mathrm{~B}$, vi). Two transitions can be clearly observed for the unfolding behavior of $\mathrm{D}_{1} \mathrm{D}_{2} \mathrm{Fc}$,

371 whereas for $D_{1} D_{2}$ was not so evident. However, analysis of $D_{1} D_{2}$ unfolding employing a

372 model considering a single transition provided illogical results (e.g. negative unfolding

373 enthalpy, which is impossible for a temperature-driven process). Using the average

374 energy of the spectrum presents two advantages: 1) signal is concentration-independent;

375 and 2) global changes in the spectrum are taken into account, that could be overlooked

376 when just paying attention to a certain wavelength. Because both proteins, $\mathrm{D}_{1} \mathrm{D}_{2} \mathrm{Fc}$ and

$377 \mathrm{D}_{1} \mathrm{D}_{2}$, contain several tryptophan residues, interpretation of the results obtained when

378 the intrinsic tryptophan fluorescence was employed as a reporter signal was somewhat

379 difficult.

380 According to the data analysis, $\mathrm{D}_{1} \mathrm{D}_{2} \mathrm{Fc}$ showed two transitions with $\mathrm{T}_{\mathrm{m}}$ 's at $40^{\circ} \mathrm{C}$ and

$38170^{\circ} \mathrm{C}$, and unfolding enthalpies of 20 and $50 \mathrm{kcal} / \mathrm{mol}$, respectively. Deletion of the $\mathrm{Fc}$

382 domain leads to a slight stabilization of the less stable region and a destabilization of the

383 more stable region (Table 1).

384

385 Isothermal titration calorimetry

$386 \mathrm{CD}$ and thermal denaturation data indicate that ICAM-1 chimera presents a proper 387 secondary and tertiary structure folding. However, this does not mean that the protein is

388 functionally active and able to recognise its natural ligands. To test $\mathrm{D}_{1} \mathrm{D}_{2} \mathrm{Fc}$ activity we 
389 have analysed the interaction of this protein with a peptide derived from its natural

390 ligand LFA-1 (DSGNIDAAKD) by isothermal titration calorimetry.

391 As shown in Figure 4 this peptide presents a high affinity for $\mathrm{D}_{1} \mathrm{D}_{2} \mathrm{Fc}$ (dissociation 392 constant $\mathrm{K}_{\mathrm{d}}$ of $0.090 \mu \mathrm{M}$ ) as expected since its sequence is derived from the integrin I 393 domain contained in the $\alpha$ subunit of LFA-1, the principal binding site for D1 of ICAM-

394 1. This result agrees with previous findings showing that this peptide inhibits the 395 homotypic T cell adhesion mediated by ICAM-1/LFA-1 interaction [51]. In addition, it 396 indicates that $\mathrm{D}_{1} \mathrm{D}_{2} \mathrm{Fc}$ is fully functional in cell-free models and able to bind a peptide 397 derived from LFA-1.

398 Moreover, our data provide for first time the dissociation constant for ICAM-1 and a peptide agonist. The value obtained $(90 \mathrm{nM})$ is lower than that previously found for the interaction between soluble monomeric ICAM-1 and the high affinity form of its natural ligand LFA-1 ( $\left.\mathrm{K}_{\mathrm{d}}: 500 \mathrm{nM}\right)$ [59] and higher than that found for dimeric ICAM-1 ( $\mathrm{K}_{\mathrm{d}}$ : 1$10 \mathrm{nM})[15,16]$. This result provides the biophysical explanation to the capacity of the peptide to block lymphocyte intercellular adhesion as previously reported [51]. In addition, it may help to design novel peptide inhibitors to target this interaction and modulate the immune response [60].

406

Binding of ICAM-1 chimera to B and T cell-associated LFA-1

ITC experiments indicate that $\mathrm{D}_{1} \mathrm{D}_{2} \mathrm{Fc}$ contains the proper folded domains involved in the interaction with a specific sequence derived from integrin I domain of LFA-1 $\alpha$.

410 However, short peptides are lineal aminoacid sequences that do not completely mimic

411 the interaction among proteins containing a three-dimensional spatial structure. Thus, to 412 proves that $\mathrm{D}_{1} \mathrm{D}_{2} \mathrm{Fc}$ is active and useful to analyse processes in which ICAM-1/LFA-1 413 interaction is involved, we have analysed the ability of the purified protein to bind the 414 native form of LFA-1 expressed on the plasma membrane of lymphoid cells. To this 415 aim we tested the ability of immobilised $\mathrm{D}_{1} \mathrm{D}_{2} \mathrm{Fc}$ to adhere LFA-1 expressing $\mathrm{B}$ cells 416 and the interaction of $\mathrm{D}_{1} \mathrm{D}_{2} \mathrm{Fc}$ and LFA-1 in $\mathrm{T}$ cells by flow cytometry (Figure 5).

417 As showed in Figure $5 \mathrm{~A}, \mathrm{D}_{1} \mathrm{D}_{2} \mathrm{Fc}$ is able to mediate the adhesion of activated $\mathrm{B}$ 418 lymphocytes showing the highest activity at a concentration of $50 \mu \mathrm{g} / \mathrm{well}$. Cells 419 incubated with medium alone or in wells coated with IgG1 show extensive clumping 420 and no adherent cells are seen. In contrast, cell clumping is much more reduced in wells 421 coated with $\mathrm{D}_{1} \mathrm{D}_{2} \mathrm{Fc}$ and several cells with fibroblast-like morphology can be detected. 
422 The quantification of cell adhesion results in a 10-fold increase related to the negative 423 IgG control.

424 The activity of this chimera to promote B cell adhesion was lower than that found 425 by using a chimera expressing the 5 domains of ICAM-1 (data not shown). It has been 426 previously reported that D1 presence on a single molecule of ICAM-1 is enough to bind 427 LFA-1 [17] [18]. However, the presence of the 5 domains of ICAM-1 provides a better 428 adhesion as previously suggested $[15,16]$. Another explanation could be that the $\mathrm{B}$ cells 429 used in this assay expresses Mac-1 that would bind through the D3 domain absent in $430 \quad \mathrm{D}_{1} \mathrm{D}_{2} \mathrm{Fc}$.

431 Next, we tested if this chimera was also useful to analyse the expression of LFA-1 432 in the cell membrane by flow cytometry. To this aim we have used the human $\mathrm{T}$ 433 leukemia Jurkat. As shown in Figure 5B the percentage of positive cells increases as it 434 increases the amount of chimera added. The performance of this chimera $\left(1 \mu \mathrm{g} / 10^{5}\right.$ 435 cells) to recognise its specific ligand (LFA-1) is similar to that of other chimeras 436 expressed and purified in native form in eukaryotic cells and used to analyse specific 437 ligands in Jurkat cells like NKG2D-Fc (data not shown). Incubation with an antiCD54 438 (ICAM-1) antibody blocked binding of the chimera (data not shown) showing that $439 \mathrm{D}_{1} \mathrm{D}_{2} \mathrm{Fc}$ is able to specifically bind to Jurkat cells through its natural ligand LFA-1.

440 As indicated above this result is supported by previous findings indicating that the

Blocking of NK-cell mediated cytotoxicity

444 The interaction of ICAM-1, expressed on tumor or virus infected cells, with LFA-1, 445 expressed on the membrane of Natural Killer (NK) cells, modulates the formation and 446 signalling of the NK immunological synapse [61]. This process is critically involved in 447 the elimination of tumor and/or virus-infected cells by NK cells [62]. In order to analyse 448 whether $\mathrm{D}_{1} \mathrm{D}_{2} \mathrm{Fc}$ was able to interfere with the cytotoxic function of NK cells, we have 449 tested the ability of this chimera to inhibit the elimination of tumor cells by human NK 450 cells. As can be seen in Figure 6 incubation with increasing amounts of $\mathrm{D}_{1} \mathrm{D}_{2} \mathrm{Fc}$ 451 completely blocked cell death induced by human NK wells on the human leukemia $452 \mathrm{~K} 562$. Control human IgG1 had no effect on this process (data not shown). Importantly, 453 inhibition was not due to the presence of the Fc region, which is known to bind and 454 activate specific receptors in NK cells, since purified $D_{1} D_{2}$ showed a similar activity. 455 Similar results were found by using the leukemic target cells Raji, Jurkat or U937 (data 
456 not shown). These results indicate that this chimera can also be used to study the 457 processes in which NK cells maybe involved. Moreover, it indicates a good biological 458 activity of the chimera since $100 \mathrm{pg}$ of protein is able to completely block cell death exerted by one NK cell.

460

\section{Conclusions}

462

To our knowledge, this is the first report on the purification of an active form of 463 ICAM-1 by using a simple and fast bacterial-based method more advantageous than mammalian models, which are very expensive and often difficult to set-up, or than other traditional folding protocols, which are time consuming and require large amounts of reagent such a refolding by dilution. In comparison with refolding by dilution, the most common protocol to purify ICAM-1 in E. coli [9], our method shows a reduction in total process time of up to $500 \%$ and decreases the cost of up to $150 \%$. If we compare it with mammalian models like HEK or COS cells, the reduction in time and money is much higher. These chimeras are of special interest to study cell adhesion assays, expression of functional ligands on cells by flow cytometry, blocking cell-cell adhesion mediated

472 processes as well as quantification of soluble ligands by ELISA. Our protocol has 473 proven useful in order to analyse several physiological processes in which ICAM474 1/LFA-1 interaction is critically involved. Moreover, it is fast and cheap, providing a 475 perfect platform in order to develop large-scale inhibitor screenings or in vivo models of 476 ICAM-1 associated pathologies, which are hard to set-up by using commercial purified proteins or other expression systems.

478

479 


\section{$480 \quad$ References}

\section{Acknowledgments}

482 This work was supported by grants 2009tw0034 from the Spanish National Research

483 Council (CSIC) and The National Science Council from Taiwan (EMG and AC),

484 SAF2011-25390 from Spanish Ministry of Economy and Competitiveness (JP) and 485 BFU2010-19451 from Spanish Ministry of Science and Innovation (AVC). JP and AVC 486 were supported by Aragón I+D (ARAID). DSM is supported by a fellowship from 487 Gobierno de Aragón. We thank Klaus Ebnet for advice regarding experimental models 488 and ICAM-1 cloning and Adriana Aporta for helping in the establishment of the 489 purification protocol.

490 
492 Table 1. Thermodynamic parameters for the unfolding of D1D2Fc and D1D2 obtained by following the thermal unfolding by intrinsic tryptophan or ANS fluorescence.

494

\begin{tabular}{lcccc}
\hline & $\mathrm{T}_{\mathrm{m} 1}\left({ }^{\circ} \mathrm{C}\right)$ & $\Delta \mathrm{H}_{1}(\mathrm{kcal} / \mathrm{mol})$ & $\mathrm{T}_{\mathrm{m} 2}\left({ }^{\circ} \mathrm{C}\right)$ & $\Delta \mathrm{H}_{2}(\mathrm{kcal} / \mathrm{mol})$ \\
\hline D1D2Fc (Trp) & $39.1 \pm 0.2$ & $20.0 \pm 0.3$ & $69 \pm 1$ & $51 \pm 1$ \\
D1D2Fc (ANS) & $40.0 \pm 0.4$ & $19.5 \pm 0.4$ & $70 \pm 1$ & $49 \pm 1$ \\
D1D2 (ANS) & $46 \pm 1$ & $23 \pm 1$ & $65 \pm 1$ & $27 \pm 1$ \\
\hline
\end{tabular}

495 


\section{Figure legends}

497 Figure 1. Schematic representation of the aminoacid sequences of the proteins

498 expressed by using the constructs pET28a- $\mathrm{D}_{1} \mathrm{D}_{2} \mathrm{Fc}$ and $\mathrm{pET} 28 \mathrm{a}-\mathrm{D}_{1} \mathrm{D}_{2}$. Numbers indicate

499 the corresponding aminoacids in human ICAM-1 sequence. Histidine tag $(\mathrm{H})$, domain 1

$500 \quad\left(D_{1}\right)$, domain $2\left(D_{2}\right)$, Linker $(L)$, human IgG1 $\mathrm{Fc}$ region $(\mathrm{Fc})$.

501 Figure 2. Analyses of the expression and purification of $D_{1} D_{2} F c D_{1} D_{2}$ in $E$. coli by

502 SDS-PAGE electrophoresis and western blot. Bacteria were transformed by using

503 pET28a- $D_{1} D_{2} F c$ or pET28a- $D_{1} D_{2}$ constructions and proteins were expressed and

504 purified as described in materials and methods. A analysis of protein overexpression in

505 bacteria by Coomassie Blue staining after SDS-PAGE. M: MW markers; 1,4: non-

506 induced transformed bacteria; 2, 3, 5, 6: bacteria induced with IPTG for $2 \mathrm{~h} \mathrm{(2} \mathrm{and} \mathrm{5)} \mathrm{or}$

$5073 \mathrm{~h}$ (3 and 6). B and D, analysis of protein refolding and purification by Coomassie Blue

508 staining after SDS-PAGE. M: MW markers; 1: induction with IPTG; 2-4 non-bound

509 proteins; 5-6: folding steps; 7-15: elution with Imidazole. $\mathbf{C}$ and $\mathbf{E}$, purified proteins

510 were separated by SDS-PAGE and analysed by western blot using antibodies specific

511 against ICAM-1 (lane 1) or poly-histidine tag (lane 2).

512 Figure 3. Spectroscopic structural characterization. A, Circular Dichroism spectra of

$513 \mathrm{D}_{1} \mathrm{D}_{2} \mathrm{Fc}$ recorded in the far ultraviolet region $(200 \mathrm{~nm}-250 \mathrm{~nm}) . \mathbf{B}$, Thermal denaturation.

514 i) Tryptophan fluorescence emission spectra of $D_{1} D_{2} F c$ (protein $2 \mu \mathrm{M}$ in PBS buffer).

515 Inset: Tryptophan fluorescence emission spectra of $\mathrm{D}_{1} \mathrm{D}_{2}$ under the same conditions; ii),

516 Thermal unfolding of $\mathrm{D}_{1} \mathrm{D}_{2} \mathrm{Fc}$ followed by tryptophan intrinsic fluorescence emission at

$517330 \mathrm{~nm}$. The temperature dependence of the fluorescence intensity at $330 \mathrm{~nm}$ was fitted

518 to a 2-transition unfolding model; iii) ANS fluorescence emission spectra of $\mathrm{D}_{1} \mathrm{D}_{2} \mathrm{Fc}$

519 (protein $2 \mu \mathrm{M}$ and ANS $100 \mu \mathrm{M}$ in PBS buffer); iv) Thermal unfolding of $\mathrm{D}_{1} \mathrm{D}_{2} \mathrm{Fc}$

520 followed by ANS fluorescence. The temperature dependence of the fluorescence

521 average energy of the ANS spectrum was fitted to a 2-transition unfolding model. A

522 similar result was obtained when the temperature dependence of the ANS fluorescence

523 emission at $470 \mathrm{~nm}$ was fitted to a 2-transition unfolding model; v) ANS fluorescence

524 emission spectra of $\mathrm{D}_{1} \mathrm{D}_{2}$. Protein $2 \mu \mathrm{M}$ and ANS $100 \mu \mathrm{M}$ in PBS buffer; vi) Thermal

525 unfolding of $\mathrm{D}_{1} \mathrm{D}_{2}$ followed by ANS fluorescence. The temperature dependence of the

526 fluorescence average energy of the ANS spectrum was fitted to a 2-transition unfolding

527 model. A similar result was obtained when the temperature dependence of the ANS

528 fluorescence emission at $470 \mathrm{~nm}$ was fitted to a 2-transition unfolding model. 
530 calorimetry (ITC). Purified $\mathrm{D}_{1} \mathrm{D}_{2} \mathrm{Fc}(12 \mu \mathrm{M})$ was titrated with a peptide derived from

531 the binding site of LFA-1 $(150 \mu \mathrm{M})$. The assay was performed in PBS buffer at $25^{\circ} \mathrm{C}$.

532 The non-linear regression analysis provided a dissociation constant of $91 \mathrm{nM}$.

533 Figure 5. Binding of $\mathbf{D}_{\mathbf{1}} \mathbf{D}_{\mathbf{2}} \mathbf{F c}$ to cell-associated LFA-1. A, B cell adhesion assay.

534 Different amounts of $\mathrm{D}_{1} \mathrm{D}_{2} \mathrm{Fc}$ or human IgG1 control were immobilised in 96 well

535 plates o.n. at $4^{\circ} \mathrm{C}$. After washing out non-bound protein, the PMA-activated R69 B cell

536 line was added by triplicates and cell adhesion was analysed by MTT as described in

537 materials and methods. Quantification of cell binding was represented as fold increase

538 with respect to the human IgG1 control. $\mathbf{B}$, analysis of $\mathrm{D}_{1} \mathrm{D}_{2} \mathrm{Fc}$ binding to LFA-1 in

539 Jurkat cells by flow cytometry. Different amounts of $\mathrm{D}_{1} \mathrm{D}_{2} \mathrm{Fc}$ or human IgG1 control

540 were incubated with Jurkat cells. After washing out non non-bound proteins cells were

541 incubated with PE-conjugated goat anti-human IgG Fc $\mathrm{Ab}$ and analysed by flow

542 cytometry. A representative histogram is shown. Numbers correspond to the \% of cells

543 as gated by the vertical bars. Black: goat anti-human IgG; Grey: human IgG1; Colour:

$544 \mathrm{D}_{1} \mathrm{D}_{2} \mathrm{Fc}$ (red: $5 \mu \mathrm{g}$; green: $10 \mu \mathrm{g}$; blue: $15 \mu \mathrm{g}$ ). Values in the graph are represented as 545 mean+/- SEM of 3 independent experiments performed by duplicate. Statistical analyses

546 were done with two-way ANOVA with Bonferroni post-test by comparing IgG with $547 \quad \mathrm{D}_{1} \mathrm{D}_{2}$ Fc. ns: not statistically significant; $* * * \mathrm{p}<0.001$.

548 Figure 6. $\mathbf{D}_{\mathbf{1}} \mathbf{D}_{\mathbf{2}} \mathbf{F c}$ inhibits NK-cell mediated cytotoxicity on tumor cells. MACS-

549 enriched human NK cells, previously stained with the fluorescence dye CFSE, were 550 incubated with $\mathrm{K} 562$ cells at $1: 1$ effector:target ratio $\left(1 \times 10^{5}\right.$ cells) for $4 \mathrm{~h}$ in the presence 551 or absence of different amounts of $\mathrm{D}_{1} \mathrm{D}_{2} \mathrm{Fc}, \mathrm{D}_{1} \mathrm{D}_{2}$ or human IgG1 control. Subsequently, 552 cell death was analysed by measuring PS translocation by flow cytometry in the CFSE 553 negative cell population (K562) as described in materials and methods. Values are 554 represented as mean+/- SEM of 2 different experiments. Statistical analyses were done 555 with two-way ANOVA with Bonferroni post-test by comparing $\operatorname{IgG}, \mathrm{D}_{1} \mathrm{D}_{2}$ and $\mathrm{D}_{1} \mathrm{D}_{2} \mathrm{Fc}$ 556 with control. ns: not statistically significant; $* * * \mathrm{p}<0.001$. 
[1] Springer TA. Adhesion receptors of the immune system. Nature 1990;346:425434.

[2] Lawson C, Wolf S. ICAM-1 signaling in endothelial cells. Pharmacol Rep 2009;61:22-32.

[3] Long EO. ICAM-1: getting a grip on leukocyte adhesion. J Immunol 2011:186:5021-5023.

[4] Fuchs R, Blaas D. Uncoating of human rhinoviruses. Rev Med Virol 2010;20:281-297.

[5] Berendt AR, McDowall A, Craig AG, Bates PA, Sternberg MJ, Marsh K, Newbold CI, Hogg N. The binding site on ICAM-1 for Plasmodium falciparum-infected erythrocytes overlaps, but is distinct from, the LFA-1binding site. Cell 1992;68:71-81.

[6] Ockenhouse CF, Betageri R, Springer TA, Staunton DE. Plasmodium falciparum-infected erythrocytes bind ICAM-1 at a site distinct from LFA1, Mac-1, and human rhinovirus. Cell 1992;68:63-69.

[7] Bernabeu M, Lopez FJ, Ferrer M, Martin-Jaular L, Razaname A, Corradin G, Maier AG, Del Portillo HA, Fernandez-Becerra C. Functional analysis of Plasmodium vivax VIR proteins reveals different subcellular localizations and cytoadherence to the ICAM-1 endothelial receptor. Cell Microbiol 2012;14:386-400.

[8] Diamond MS, Staunton DE, Marlin SD, Springer TA. Binding of the integrin Mac-1 (CD11b/CD18) to the third immunoglobulin-like domain of ICAM-1 $\underline{\text { CD54) and its regulation by glycosylation. Cell 1991;65:961-971. }}$

[9] Martin S, Martin A, Staunton DE, Springer TA. Functional studies of truncated soluble intercellular adhesion molecule 1 expressed in Escherichia coli. Antimicrob Agents Chemother 1993;37:1278-1284.

[10] Staunton DE, Dustin ML, Erickson HP, Springer TA. The arrangement of the immunoglobulin-like domains of ICAM-1 and the binding sites for LFA-1 and rhinovirus. Cell 1990;61:243-254.

[11] Landis RC, McDowall A, Holness CL, Littler AJ, Simmons DL, Hogg N. Involvement of the "I" domain of LFA-1 in selective binding to ligands ICAM-1 and ICAM-3. J Cell Biol 1994;126:529-537.

[12] Huang C, Springer TA. A binding interface on the I domain of lymphocyte function-associated antigen-1 (LFA-1) required for specific interaction with intercellular adhesion molecule 1 (ICAM-1). J Biol Chem 1995;270:1900819016. 
[13] Staunton DE, Merluzzi VJ, Rothlein R, Barton R, Marlin SD, Springer TA. A cell adhesion molecule, ICAM-1, is the major surface receptor for rhinoviruses. Cell 1989;56:849-853.

[14] Duperray A, Languino LR, Plescia J, McDowall A, Hogg N, Craig AG, Berendt AR, Altieri DC. Molecular identification of a novel fibrinogen binding site on the first domain of ICAM-1 regulating leukocyteendothelium bridging. J Biol Chem 1997;272:435-441.

[15] Miller J, Knorr R, Ferrone M, Houdei R, Carron CP, Dustin ML. Intercellular adhesion molecule-1 dimerization and its consequences for adhesion mediated by lymphocyte function associated-1. J Exp Med 1995;182:1231-1241.

[16] Reilly PL, Woska JR, Jr., Jeanfavre DD, McNally E, Rothlein R, Bormann BJ. The native structure of intercellular adhesion molecule-1 (ICAM-1) is a dimer. Correlation with binding to LFA-1. J Immunol 1995;155:529-532.

[17] Casasnovas JM, Stehle T, Liu JH, Wang JH, Springer TA. A dimeric crystal structure for the N-terminal two domains of intercellular adhesion molecule-1. Proc Natl Acad Sci U S A 1998;95:4134-4139.

[18] Jun CD, Shimaoka M, Carman CV, Takagi J, Springer TA. Dimerization and the effectiveness of ICAM-1 in mediating LFA-1-dependent adhesion. Proc Natl Acad Sci U S A 2001;98:6830-6835.

[19] Martin S, Heidenthal E, Schulte B, Rothe H, Kolb H. Soluble forms of intercellular adhesion molecule-1 inhibit insulitis and onset of autoimmune diabetes. Diabetologia 1998;41:1298-1303.

[20] Oh HM, Kwon MS, Kim HJ, Jeon BH, Kim HR, Choi HO, Na BR, Eom SH, Song NW, Jun CD. Intermediate monomer-dimer equilibrium structure of native ICAM-1: implication for enhanced cell adhesion. Exp Cell Res 2011;317:163-172.

[21] Springer TA. Traffic signals for lymphocyte recirculation and leukocyte emigration: the multistep paradigm. Cell 1994;76:301-314.

[22] Millan J, Hewlett L, Glyn M, Toomre D, Clark P, Ridley AJ. Lymphocyte transcellular migration occurs through recruitment of endothelial ICAM-1 to caveola- and F-actin-rich domains. Nat Cell Biol 2006;8:113-123.

[23] Springer TA, Dustin ML. Integrin inside-out signaling and the immunological synapse. Curr Opin Cell Biol 2012;24:107-115.

[24] Frank PG, Lisanti MP. ICAM-1: role in inflammation and in the regulation of vascular permeability. Am J Physiol Heart Circ Physiol 2008;295:H926H927. 
[25] Kobavashi H, Boelte KC, Lin PC. Endothelial cell adhesion molecules and cancer progression. Curr Med Chem 2007;14:377-386.

[26] Rosette C, Roth RB, Oeth P, Braun A, Kammerer S, Ekblom J, Denissenko MF. Role of ICAM1 in invasion of human breast cancer cells. Carcinogenesis 2005;26:943-950.

[27] Miele ME, Bennett CF, Miller BE, Welch DR. Enhanced metastatic ability of TNF-alpha-treated malignant melanoma cells is reduced by intercellular adhesion molecule-1 (ICAM-1, CD54) antisense oligonucleotides. Exp Cell Res 1994;214:231-241.

[28] Zheng Y, Yang J, Qian J, Qiu P, Hanabuchi S, Lu Y, Wang Z, Liu Z, Li H, He J, Lin P, Weber D, Davis RE, Kwak L, Cai Z, Yi Q. PSGL-1/selectin and ICAM-1/CD18 interactions are involved in macrophage-induced drug resistance in myeloma. Leukemia 2012.

[29] Iigo Y, Takashi T, Tamatani T, Miyasaka M, Higashida T, Yagita H, Okumura K, Tsukada W. ICAM-1-dependent pathway is critically involved in the pathogenesis of adjuvant arthritis in rats. J Immunol 1991;147:41674171.

[30] Galkina E, Ley K. Vascular adhesion molecules in atherosclerosis. Arterioscler Thromb Vasc Biol 2007;27:2292-2301.

[31] Eksteen B, Liaskou E, Adams DH. Lymphocyte homing and its role in the pathogenesis of IBD. Inflamm Bowel Dis 2008;14:1298-1312.

[32] Thomas $S$, Baumgart DC. Targeting leukocyte migration and adhesion in Crohn's disease and ulcerative colitis. Inflammopharmacology 2012;20:1$\underline{18 .}$

[33] Huang WC, Chan ST, Yang TL, Tzeng CC, Chen CC. Inhibition of ICAM-1 gene expression, monocyte adhesion and cancer cell invasion by targeting IKK complex: molecular and functional study of novel alpha-methylenegamma-butyrolactone derivatives. Carcinogenesis 2004;25:1925-1934.

[34] Shimaoka M, Springer TA. Therapeutic antagonists and the conformational regulation of the beta 2 integrins. Curr Top Med Chem 2004;4:1485-1495.

[35] Anderson ME, Siahaan TJ. Targeting ICAM-1/LFA-1 interaction for controlling autoimmune diseases: designing peptide and small molecule inhibitors. Peptides 2003;24:487-501.

[36] Porath J, Carlsson J, Olsson I, Belfrage G. Metal chelate affinity chromatography, a new approach to protein fractionation. Nature 1975;258:598-599. 
[37] Hutchens TW, Yip TT. Protein interactions with immobilized transition metal ions: quantitative evaluations of variations in affinity and binding capacity. Anal Biochem 1990;191:160-168.

[38] Lilie H, Schwarz E, Rudolph R. Advances in refolding of proteins produced in E. coli. Curr Opin Biotechnol 1998;9:497-501.

[39] Zardeneta G, Horowitz PM. Protein refolding at high concentrations using detergent/phospholipid mixtures. Anal Biochem 1994;218:392-398.

[40] Gu Z, Weidenhaupt M, Ivanova N, Pavlov M, Xu B, Su ZG, Janson JC. Chromatographic methods for the isolation of, and refolding of proteins from, Escherichia coli inclusion bodies. Protein Expr Purif 2002;25:174$\underline{179 .}$

[41] Shalongo W, Ledger R, Jagannadham MV, Stellwagen E. Refolding of denatured thioredoxin observed by size-exclusion chromatography. Biochemistry 1987;26:3135-3141.

[42] Fahey EM, Chaudhuri JB, Binding P. Refolding and purification of a urokinase plasminogen activator fragment by chromatography. J Chromatogr B Biomed Sci Appl 2000;737:225-235.

[43] Schlegl R, Iberer G, Machold C, Necina R, Jungbauer A. Continuous matrixassisted refolding of proteins. J Chromatogr A 2003;1009:119-132.

[44] Geng X, Bai Q, Zhang Y, Li X, Wu D. Refolding and purification of interferon-gamma in industry by hydrophobic interaction chromatography. J Biotechnol 2004;113:137-149.

[45] Stempfer G, Holl-Neugebauer B, Rudolph R. Improved refolding of an immobilized fusion protein. Nat Biotechnol 1996;14:329-334.

[46] Umakoshi H, Persson J, Kroon M, Johansson HO, Otzen DE, Kuboi R, Tjerneld F. Model process for separation based on unfolding and refolding of chymotrypsin inhibitor 2 in thermoseparating polymer two-phase systems. J Chromatogr B Biomed Sci Appl 2000;743:13-19.

[47] Oganesyan N, Kim SH, Kim R. On-column protein refolding for crystallization. J Struct Funct Genomics 2005;6:177-182.

[48] Rogl H, Kosemund K, Kuhlbrandt W, Collinson I. Refolding of Escherichia coli produced membrane protein inclusion bodies immobilised by nickel chelating chromatography. FEBS Lett 1998;432:21-26.

[49] Colangeli R, Heijbel A, Williams AM, Manca C, Chan J, Lyashchenko K, Gennaro ML. Three-step purification of lipopolysaccharide-free, polyhistidine-tagged recombinant antigens of Mycobacterium tuberculosis. J Chromatogr B Biomed Sci Appl 1998;714:223-235. 
[50] Lemercier C, Legube G, Caron C, Louwagie M, Garin J, Trouche D, Khochbin S. Tip60 acetyltransferase activity is controlled by phosphorylation. J Biol Chem 2003;278:4713-4718.

[51] Tibbetts SA, Seetharama Jois D, Siahaan TJ, Benedict SH, Chan MA. Linear and cyclic LFA-1 and ICAM-1 peptides inhibit $T$ cell adhesion and function. Peptides 2000;21:1161-1167.

[52] Paradela A, Garcia-Peydro M, Vazquez J, Rognan D, Lopez de Castro JA. The same natural ligand is involved in allorecognition of multiple HLA-B27 subtypes by a single T cell clone: role of peptide and the MHC molecule in alloreactivity. J Immunol 1998;161:5481-5490.

[53] Rothlein R, Dustin ML, Marlin SD, Springer TA. A human intercellular adhesion molecule (ICAM-1) distinct from LFA-1. J Immunol 1986;137:1270-1274.

[54] Alley MC, Scudiero DA, Monks A, Hursey ML, Czerwinski MJ, Fine DL, Abbott BJ, Mayo JG, Shoemaker RH, Boyd MR. Feasibility of drug screening with panels of human tumor cell lines using a microculture tetrazolium assay. Cancer Res 1988;48:589-601.

[55] Bernardo I, Mancebo E, Aguilo I, Anel A, Allende LM, Guerra-Vales JM, Ruiz-Contreras J, Serrano A, Talayero P, de la Calle O, GonzalezSantesteban C, Paz-Artal E. Phenotypic and functional evaluation of CD3+CD4-CD8- T cells in human CD8 immunodeficiency. Haematologica 2011;96:1195-1203.

[56] Pardo J, Galvez EM, Koskinen A, Simon MM, Lobigs M, Regner M, Mullbacher A. Caspase-dependent inhibition of mousepox replication by gzmB. PLoS One 2009;4:e7512.

[57] Glynou K, Ioannou PC, Christopoulos TK. One-step purification and refolding of recombinant photoprotein aequorin by immobilized metal-ion affinity chromatography. Protein Expr Purif 2003;27:384-390.

[58] Staunton DE, Marlin SD, Stratowa C, Dustin ML, Springer TA. Primary structure of ICAM-1 demonstrates interaction between members of the immunoglobulin and integrin supergene families. Cell 1988;52:925-933.

[59] Tominaga Y, Kita Y, Satoh A, Asai S, Kato K, Ishikawa K, Horiuchi T, Takashi $T$. Affinity and kinetic analysis of the molecular interaction of ICAM-1 and leukocyte function-associated antigen-1. J Immunol 1998;161:4016-4022.

[60] Zhou CL, Lu R, Lin G, Yao Z. The latest developments in synthetic peptides with immunoregulatory activities. Peptides 2011;32:408-414. 
744

745

746

747

748

749

750

751
[61] Liu D, Bryceson YT, Meckel T, Vasiliver-Shamis G, Dustin ML, Long EO. Integrin-dependent organization and bidirectional vesicular traffic at cytotoxic immune synapses. Immunity 2009;31:99-109.

[62] Bryceson YT, March ME, Barber DF, Ljunggren HG, Long EO. Cytolytic granule polarization and degranulation controlled by different receptors in resting NK cells. J Exp Med 2005;202:1001-1012. 
- we have established a fast and cost-effective method to produce recombinant human ICAM-1

- ICAM-1 presents a proper folding as revealed by analyses of secondary and tertiary structure

- purified ICAM-1 is highly active and proves useful for biochemical, immunological and cell biology studies.

- ICAM-1 has been used to calculate the dissociation constant of peptide inhibitors used to treat inflammatory disorders 
Figure 2

A

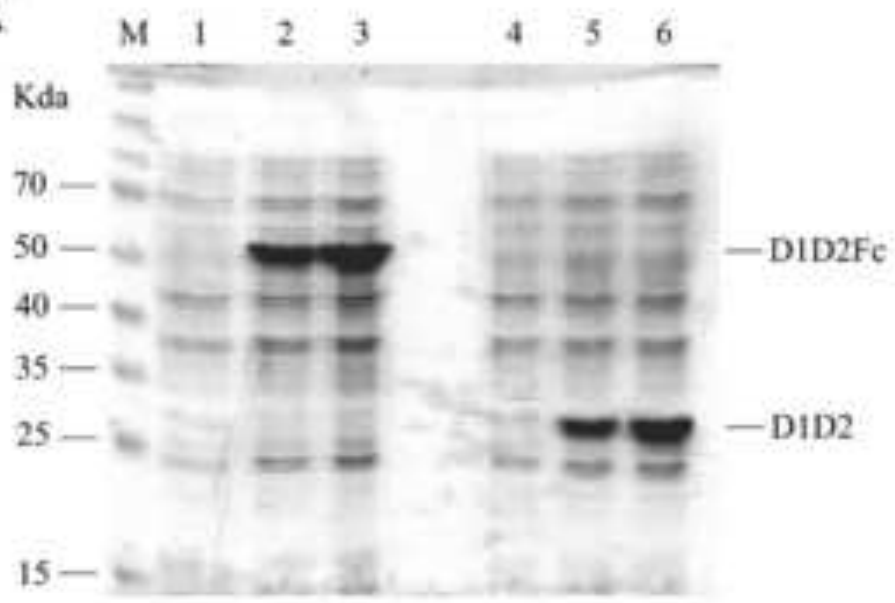

B

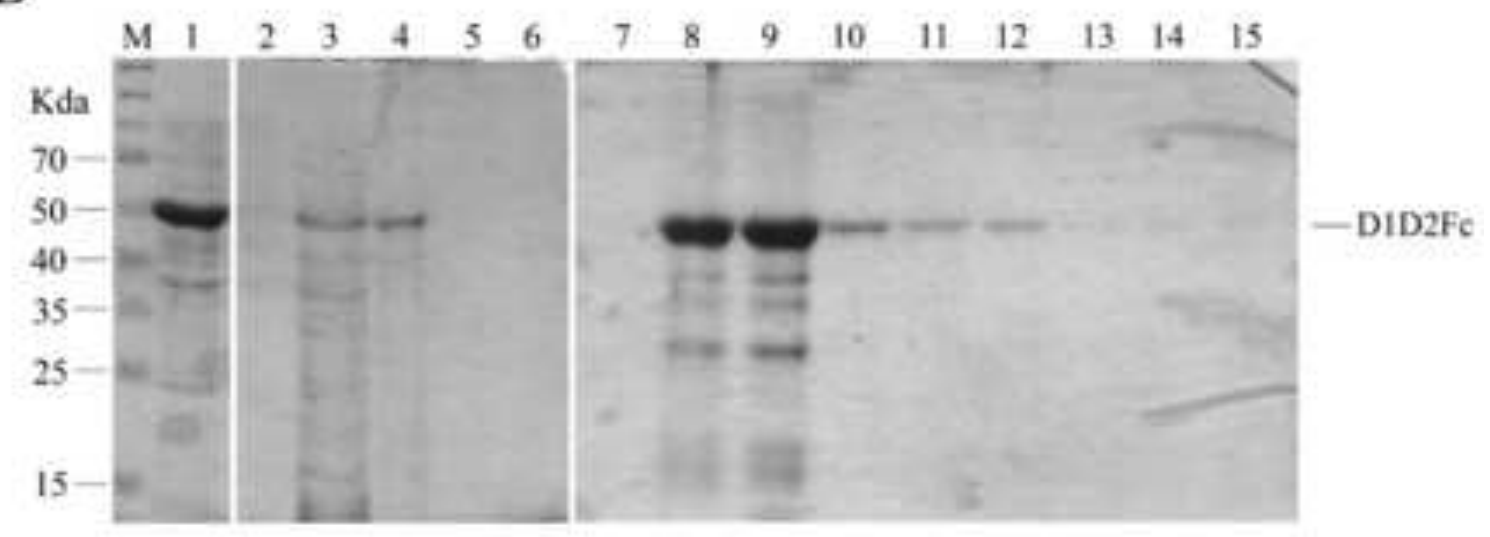

C

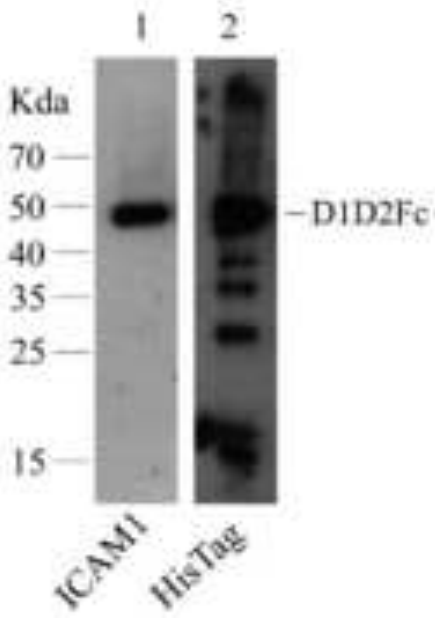

D

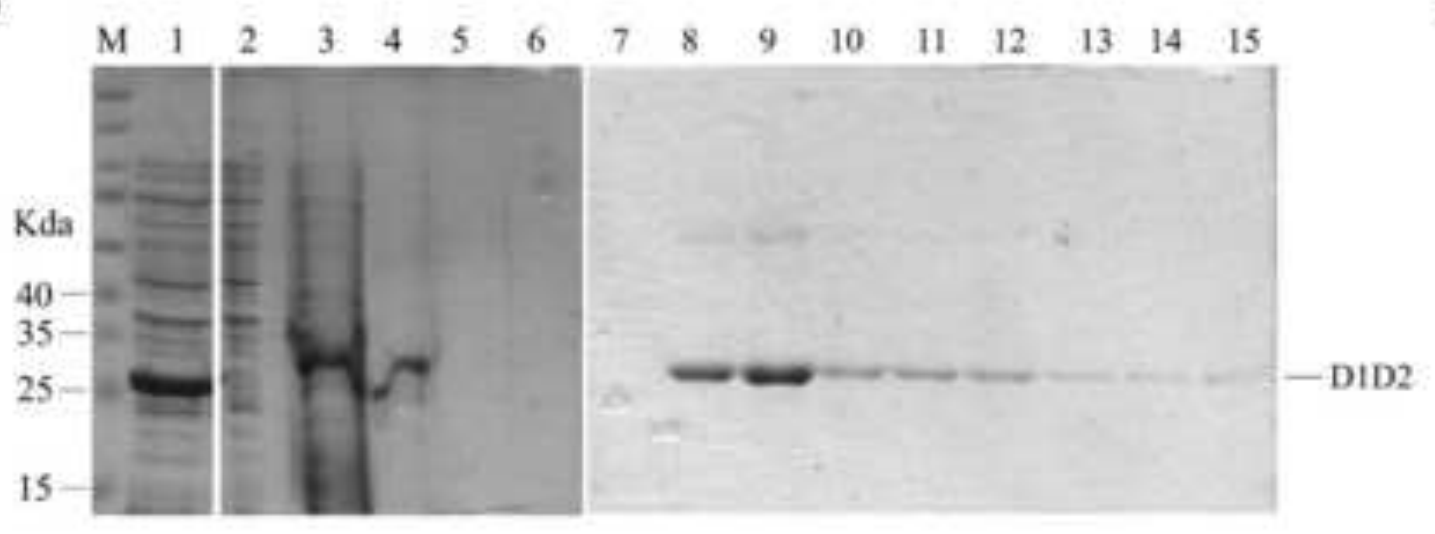

E

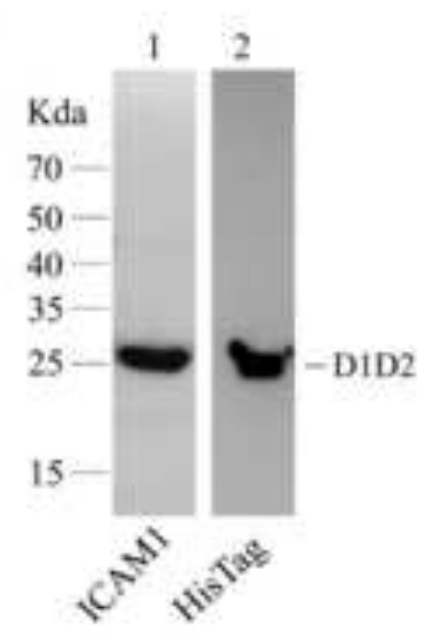


Figure 3

A

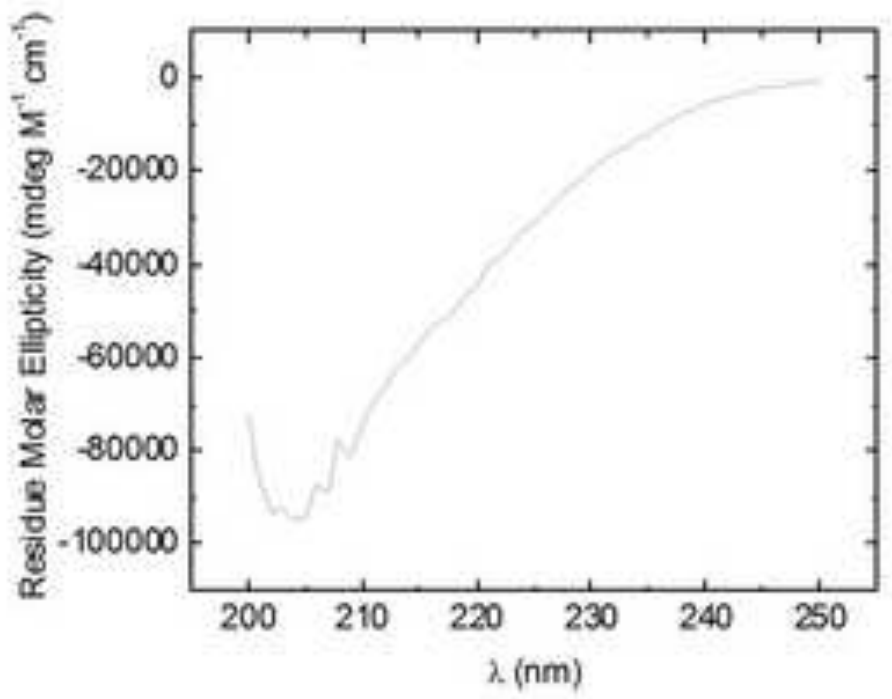

B
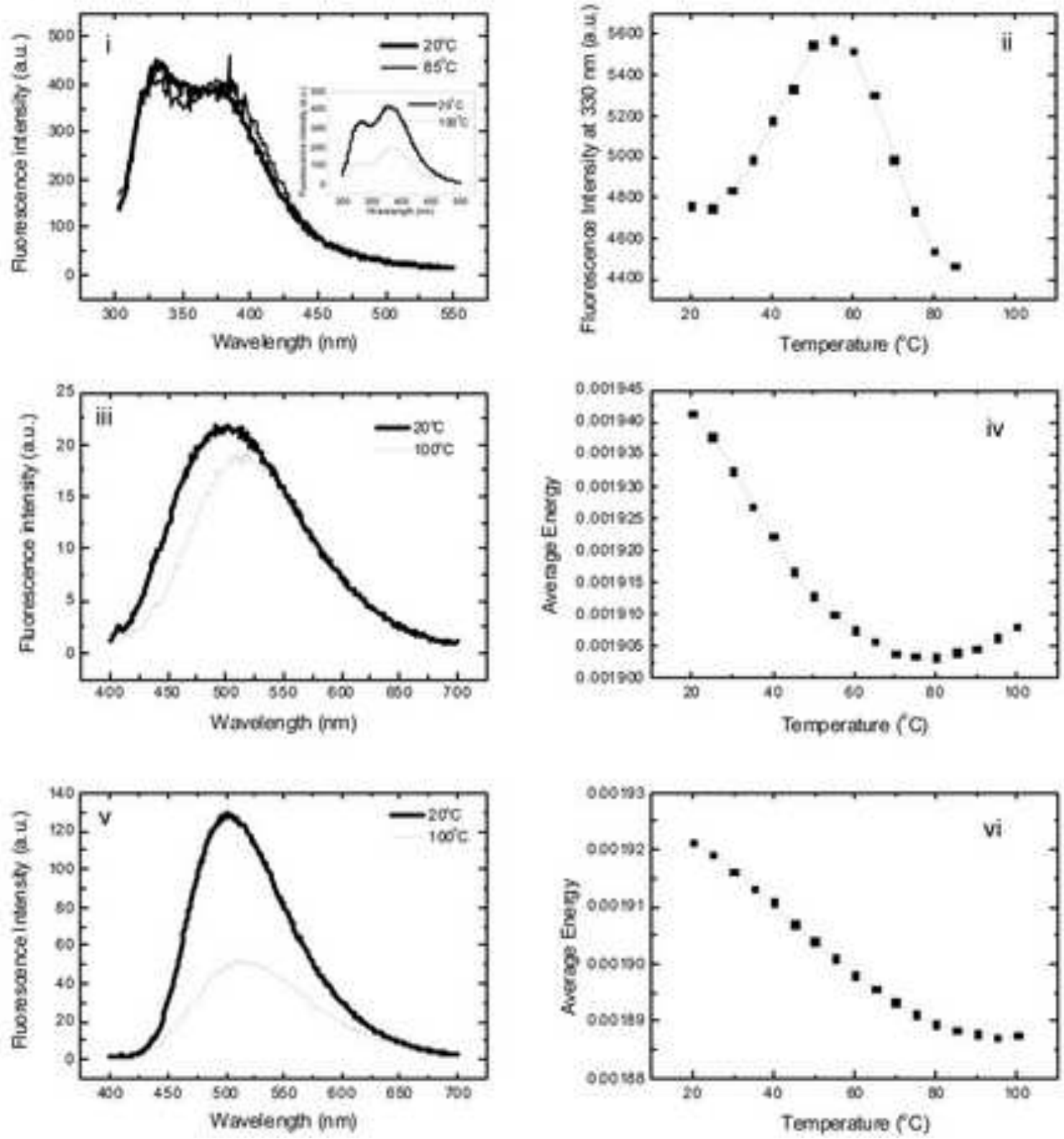
Figure 4

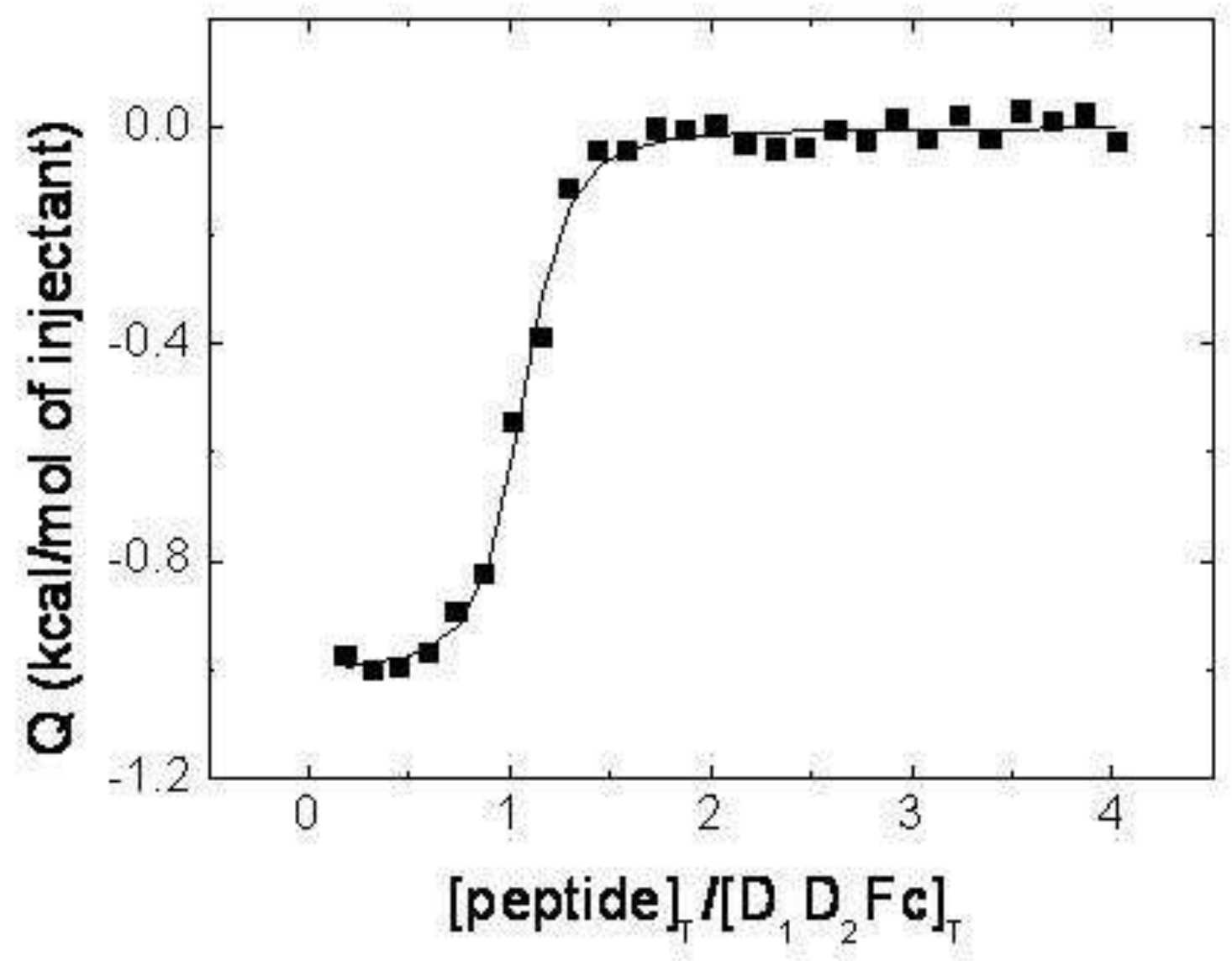


Figure 5

A

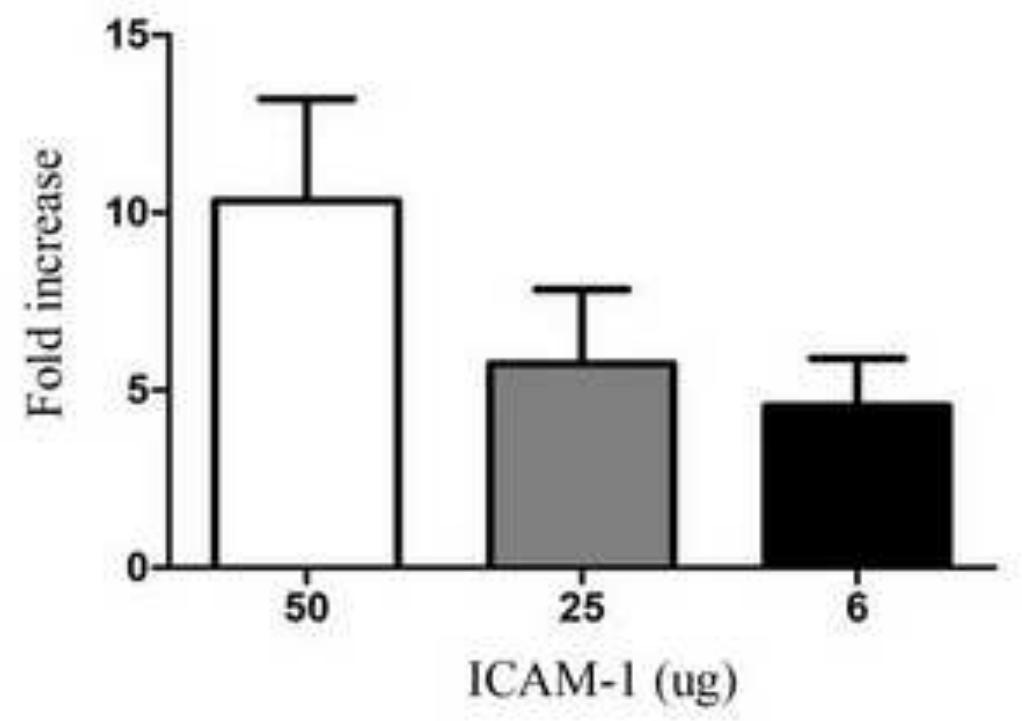

B
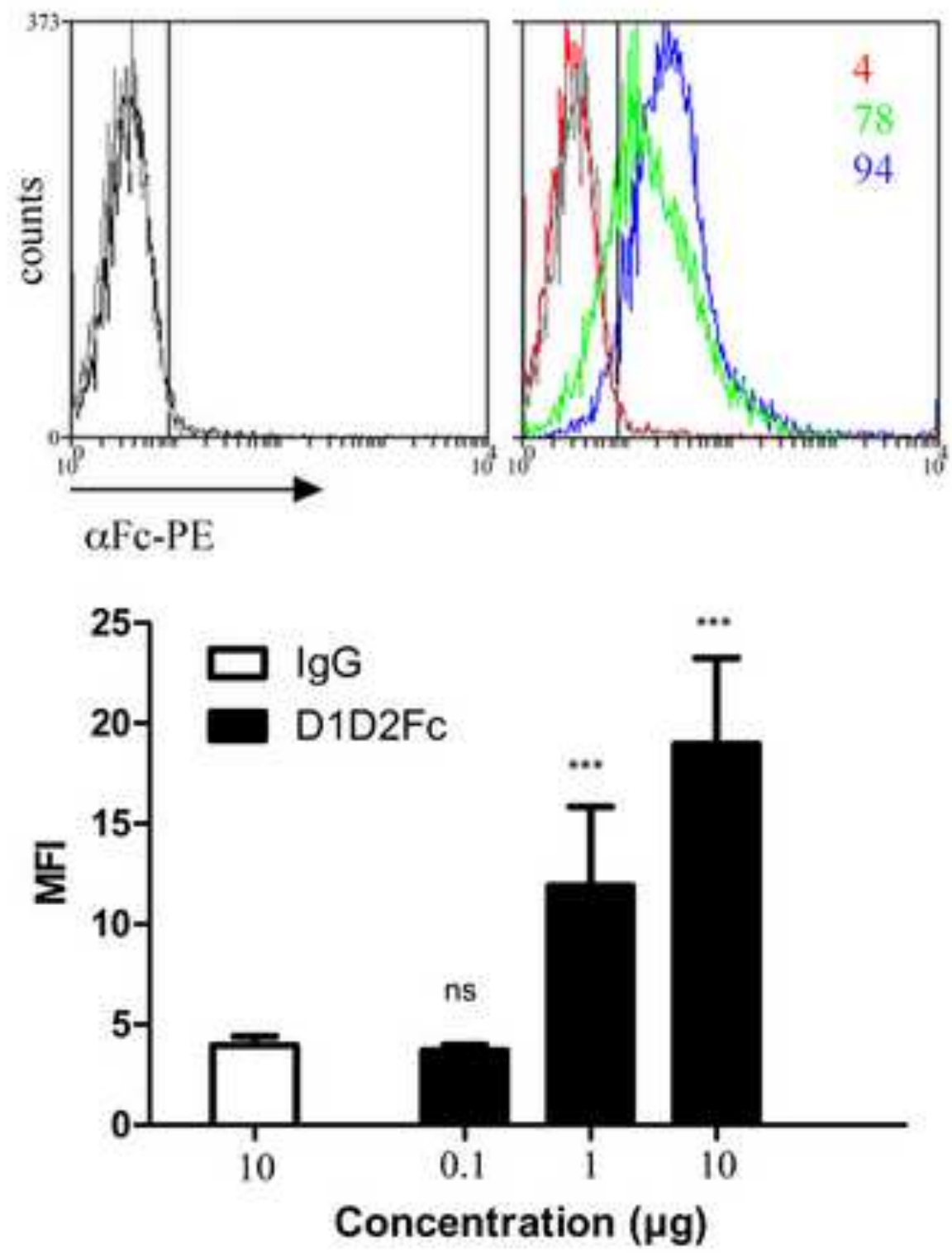
Figure 6

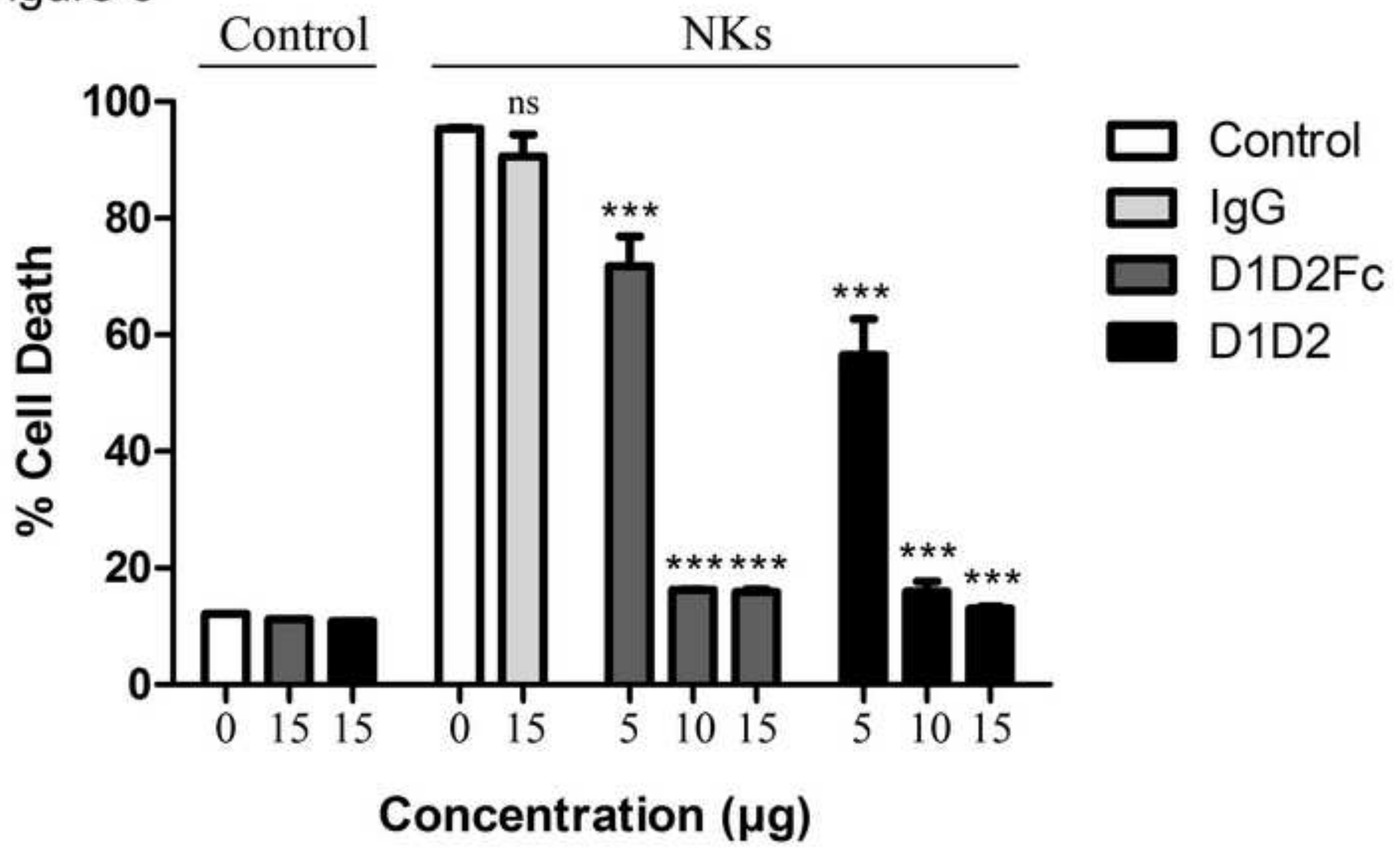

